\title{
Do practitioners of holistic management exhibit systems thinking?
}

\author{
Carolyn Mann $^{1}, \underline{\text { John R. Parkins }}^{2}, \underline{\text { Marney E. Isaac }}^{3,4}$ and Kate Sherren $^{1}$
}

\begin{abstract}
Holistic management (HM) is a decision-making framework, first developed in grazing systems, which combines intensive, rapid rotation of grazing livestock with adaptive and holistic decision making. Holistic management's use of systems thinking concepts may help farmers cope with increasing complexity on their farms. We used Q-methodology, a mixed method approach for identifying discourses, to understand the levels and types of systems thinking employed by farmers and HM trainers along a gradient of HM engagement. With responses from 18 Canadian and American participants, we identified 3 main viewpoints: the Fluent Systems Thinker, with adherence to core systems ideas such as tackling root causes and mimicking nature; the Aspirational Systems Balancer, who appreciates systems thinking ideas but struggles with application; and the Independent Creative Farmer, who adheres to more conventional farming traditions but values creativity and learning. These groups differed in their levels of empowerment, creativity, goal setting, and willingness to learn, all of which can affect capacity to manage complex decisions. All but one participating HM trainer were Fluent Systems Thinkers, suggesting the alignment of HM with systems thinking. All three of our participating females fell under the Aspirational Systems Balancer, suggesting lower levels of empowerment. We concluded that stronger engagement with HM correlates with higher adherence to systems thinking ideas and different types of systems thinking, although more research is needed to explore the direction of causation, the role of gender, and the ultimate effects on farm outcomes.
\end{abstract}

Key Words: adaptive multipaddock grazing (AMP); agroecology; complex systems; holism; holistic management; Q methodology

\section{INTRODUCTION}

Rangelands, the large grass-dominated areas in which unreliable rainfall limits agriculture to livestock grazing, face unprecedented levels of degradation (Yirdaw et al. 2017). Historically, efforts were made in rangeland management to establish sustainable grazing levels using concepts such as plant community succession, but the complexity, scale, and variability of these environments led to multiple stable states confounding the possibility of using climax as a diagnostic tool (Sayre 2017). Many rangeland researchers have shifted to alternative approaches such as stateand-transition models but those remain limited in their application (Bestelmeyer et al. 2018). Rangelands have particularly suffered from reductionist and technocratic government policies that diminish system resilience and ignore local socioeconomic needs and goals ( $\mathrm{Li}$ and Li 2012, Allsopp 2013, Linstaedter et al. 2016).

Holistic management (HM) was developed in the 1980s by Allan Savory, an ecologist and livestock farmer, to confront these negative trends (Savory 2016). Savory built on traditions of pastoralism to mimic natural predator-grazer relationships through adaptive, rapid rotation of high numbers of grazing livestock through many paddocks (Savory 2016). His method advocates embedding agricultural decision making within a cycle of goal setting, planning, monitoring, and adaptation. Although $\mathrm{HM}$ is generally applied in livestock grazing, it is applicable for other commodities and, like permaculture, beyond farming entirely (Mannen et al. 2012, Mann and Sherren 2018).

Social science and farm-scale management research on HM have largely described positive outcomes, in part through talking to practitioners (Sherren et al. 2012, de Villiers et al. 2014, Nordborg and Röös 2016, Sherren and Kent 2019). Proponents have claimed huge successes: improved range condition, livestock productivity, farmer income and quality of life, soil health, carbon sequestration, and higher emergy sustainability (Stinner et al. 1997, Jacobo et al. 2006, Alfaro-Arguello et al. 2010, de Villiers et al. 2014). More recently, Savory himself controversially extended those claims to include reversing desertification, halting climate change, and ending poverty (Savory 2016; Savory, 2013 TED Talk https://www.ted.com/talks/allan_savory how to green the world $\mathrm{s}$ deserts and reverse climate change?language= en). Experimental science typically does not support such claims (Holechek and Valdez 2000, Briske et al. 2008, Carter et al. 2014, Hawkins 2017, Sherren and Kent 2019) but has been criticized for disregarding the important adaptive decision-making component of the system (Briske et al. 2011, Savory 2016, Sherren and Kent 2019).

Both natural scientists and social scientists agree that HM practitioners benefit from using systems thinking, for instance, by embracing complexity, adaptivity, and holism (Briske et al. 2011, 2014, Nordborg and Röös 2016). Although reductionist thinking is useful in some contexts, systems thinking has long been recognized as a useful tool for improving capacity to deal with uncertainty and complexity in agriculture (Bawden 1991, Bosch et al. 2007, Mitchell et al. 2016). Researchers have argued that methods from complex systems thinking could help contextualize rangeland problems and formulate management responses (Bosch et al. 2007), improve livelihoods and rangeland condition (Allsopp 2013), recouple social and ecological rangeland systems (Li and Li 2012), and improve management of rangeland commons (Robinson 2009). Holistic management practitioners themselves seem to show higher adaptive capacity, social capital and innovation (de Villiers et al. 2014), employ longterm systematic thinking, and embrace landscape heterogeneity (Sherren et al. 2012).

${ }^{1}$ School for Resource and Environmental Studies, Dalhousie University, Halifax, ${ }^{2}$ Department of Resource Economics and Environmental Sociology, University of Alberta, Edmonton, ${ }^{3}$ Department of Physical and Environmental Sciences and the Centre for Critical Development Studies, University of Toronto Scarborough, Ontario, ${ }^{4}$ Department of Geography, University of Toronto 
Systems thinking represents a sharp break from the reductionist "command and control" thinking that has been described as dominating conventional agriculture, and which by seeking to control natural variation has reduced overall resilience (Holling and Meffe 1996, Abaidoo and Dickinson 2002). Though there are many schools of thought within the systems thinking field, we define it as "the ability to represent and assess dynamic complexity" (Sweeney and Sterman 2000:2), which is similar to the concept of "complex systems methods" described elsewhere (Schiere et al. 2004). This fundamentally different mindset aims to understand and affect change in nested and interconnected systems (Bennet and Bennet 2008, Meadows 2008). Systems thinking relies on concepts such as holism (interconnectedness, in which the whole is more than a sum of its parts), complexity (interactions among multiple variables means the system cannot be understood in terms of direct cause-effect relationships), and resiliency (ability to survive, recover from shocks, and persist in variable situations; the opposite of brittleness; Bennet and Bennet 2008, Meadows 2008). Systems thinkers critically engage with the lens through which they view the world; though we are each trapped in our own paradigm, systems thinkers work hard to understand their paradigm, shift paradigms, or ideally, transcend paradigms altogether (Meadows 2008).

An early review assembled a humbling list of reasons for human failure in complex systems: hidden system components or structures, dynamic complexity, time delays, inability to conduct experiments, selective perception, nonlinearities, missing feedback, delays, biases, distortions, ambiguities, and the list goes on (Sterman 1994). Given this, it would be unrealistic to expect all farmers to become systems thinking experts, however, even a modicum of systems thinking skills would likely help farmers deal with the increasing complexity of farming (Bawden 1991, Bosch et al. 2007, Robinson 2009, Allsopp 2013). Systems thinking has been applied in agriculture through: agricultural innovation systems (Spielman 2005, Klerkx et al. 2010); social-ecological systems (SES; Brunson 2012, Linstaedter et al. 2016, Hahn and Nykvist 2017, Hruska et al. 2017); farming systems research and systems agriculture (Bawden 1991, Schiere et al. 2004); agroecology, which integrates agronomy with ecology and socioeconomics (Dalgaard et al. 2003); and, permaculture, in which farmers create sustainable agro-social systems by mimicking natural patterns (King 2008). Beyond its agricultural applications, systems thinking has also been identified as valuable in other planning and management settings, such as ecosystembased management in ecology (Potschin and Haines-Young 2013), forestry (Bosch et al. 2007), and fisheries (Berkes 2003).

Although HM has also been described as systems thinking in practice (Mann and Sherren 2018), it remains unclear to what extent HM practitioners themselves employ systems thinking. Holistic management is a heterogeneous concept, in which farmers can adopt new paradigms as well as new practices, and in which trainers focus more on building decision-making skills than defining a set of grazing rules (Mann and Sherren 2018). In reality, among practitioners, there is a wide range in the uptake of various HM elements. Some may do as little as rapidly rotating their animals through many pastures, whereas others embrace concepts like holistic decision making, interconnectivity, and adaptability (Mann and Sherren 2018). This heterogeneity complicates discussions of adoption (de Villiers et al. 2014) and creates a challenging environment for academic research, which prefers to draw clean boundaries between different grazing practices.

The heterogeneity among HM practitioners suggests a gradient of systems thinking capacity and application, ranging from those with minimal HM experience or low HM application, to expert levels. Individuals who engage with HM to varying degrees and in different contexts will undoubtedly bring their own subjectivities to HM. The goal of this study was to understand the subjective adherence to systems thinking among people (farmers and HM trainers) who self-identify as engaging in HM to varying degrees. We used an online Q method survey of HM trainers, long-time HM-practitioners, and new or "somewhat HM" farmers to respond to two research questions:

1. Are there different levels of systems thinking among people engaged in HM to varying degrees?

2. Are there different types of systems thinkers among these groups, i.e., do they emphasize different systems thinking ideas?

\section{Q METHODOLOGY}

We used Q methodology, an exploratory mixed-method approach for identifying discourse on a given subject, to assess farmers' subjective worldviews, and to understand the level and types of systems thinking they employ. We developed a group of statements (Q set) to comprise the concourse, which represents the full range of potential opinions or views on a given subject, in this case systems thinking in farming operations. Participants were asked to sort this series of statements along a scale from strongly agree to strongly disagree on a forced-normal distribution. In this way, only a minority of statements can be placed at the extreme ends of the scale and the bulk of statements must be placed in the middle categories (Brown 1980, 1993; J. van Exel and G. de Graaf 2005, https://qmethodblog.files.wordpress. com/2016/01/qmethodologyasneakpreviewreferenceupdate.pdf). The way in which a participant arranges the statements is known as the "Q sort." These data are then subjected to factor analysis, thereby allowing quantitative assessment of qualitative worldviews. Recent work has found that the cognitive task of Q sorting is similar to responding to comparable statements using a Likert scale, but the forced choice elicits clearer priorities across a larger number of statements within the Q set (Thompson et al. 2013; Parkins and Sherren, in press).

Q methodology has now been widely used to understand environmental views and elicit farmers' and ranchers' perceptions on a range of farm-related issues. $\mathrm{Q}$ has revealed interesting differences in farmers' decision making and management styles on a range of levels. From a paradigmatic view, for example, it has revealed differences between holistic and reductionist viewpoints in agroecology (Louah et al. 2017); different strategies among progressive beef farmers, from the "committed environmentalist" to the "profit maximizer" (Pereira et al. 2016); and variations in how Swiss alpine farmers use common resources and enforce prosocial behavior (Baur et al. 2014). Q methodology has shown that farmers and ranchers generally share some level of conservationism and land ethic, while still holding divergent views in other topics (Davies and Hodge 2007, Lien et al. 2017). It is also useful for understanding day-to-day decisions, such as 
motivators for making crop decisions (Nordhagen et al. 2017) or preferences about height and color of vegetation (Cruz et al. 2007). Farmers are a diverse group, and the strength of $Q$ is its ability to reveal distinct discourses within agriculture that can help direct future policies and programs (Brodt et al. 2006, Hall and Wreford 2012, Hamadou et al. 2016).

\section{Developing the $\mathbf{Q}$ set}

An initial Q set of 88 statements about goal setting, planning, and decision making was developed by drawing on ideas and discourses in systems thinking literature, from previous academic work using Q methodology on farms and ranches, our interviews with adaptive grazing trainers in fall 2017 (Mann and Sherren 2018), and HM literature and training materials. Our goal was to assess adherence not to HM practices but to systems thinking ideas in an agricultural context, some of which overlap with HM tenets. Further, this method does not allow us to assess participants' capacity for systems thinking, nor their on-farm actions or outcomes, but only their stated value for systems thinking ideas. Because the selection of the Q sample is of critical importance (Brown 1980), we worked to ensure that statements were clear and easy to understand, and represented a wide scope of issues and ideas in systems thinking and decision making.

Statements were developed within 11 categories: quality of life; goals and planning (short-term vs. long-term thinking); problem solving and decision making; creativity/flexibility; diversity and resilience (risk management); monitoring outcomes; empowerment; boundaries; social; economic/productivity; and environment. Many of the categories are not mutually exclusive, and thus some statements could reasonably fit into multiple categories. Within each category, statements were developed to represent both the traditional/reductionist view and the systemic view, though these delineations are not "hard." Statements were selected so that each category contained at least one systems statement and at least one traditional/reductionist statement. The final Q set of 30 statements was refined with help from a colleague who recently completed interviews with Canadian ranchers across a range of rotational regimes.

\section{Survey design}

The Q sort itself was conducted through Q-sorTouch (Pruneddu 2016), an online Q method platform that allows the administering of additional survey questions alongside the Q sort. Participants were presented with the 30 statements in random order and asked to rank them on a scale from -3 (strongly disagree) to +3 (strongly agree) in a forced-normal distribution. This range is not as wide as is typically used, but was chosen to make the sorting task easier for participants on a laptop screen without requiring too much scrolling from side to side. The range and shape of the distribution have no effect on analysis (Brown 1993). We estimated the survey would take 20-30 minutes to complete. All participants were sent a $\$ 10$ Amazon gift voucher in local currency for completing the survey if they provided an email address: 16 of 18 did.

Although the platform is somewhat intuitive, we had feedback from several potential respondents who were not able to complete the survey, either because the platform did not work well on mobile devices or because the system defaults prevented them from continuing through the survey. This latter issue was possibly because the participant had not provided an answer to every question, a requirement that the system does not explain well. We likely lost some potential participants because of these software issues, although the exact number is not known.

\section{Participant recruitment}

We deliberately stratified our sampling to engage participants along a gradient of HM engagement. We sent the survey to 50 Canadian and American HM trainers who had participated in or expressed interest in our previous research on HM training (Mann and Sherren 2018) and asked them to also send the survey to their recent trainees. Our initial plan was to track a systems thinking trajectory based on self-identified adherence to HM, ranging from trainees with little or no HM experience, to those with significant HM experience, including the trainers. However, most of the trainees we heard from had already taken prior HM training, so we had no effective control sample. We thus asked the abovementioned colleague to send the survey to an additional 50 farmer participants from her recent grazing study, and this way we acquired a few somewhat and non-HM farmers. It can be difficult to recruit conventional farmers in such research because selfselection bias filters out only those who are comfortable with the domains being discussed. This can lead to a set of usual suspects regularly participating in research, making it difficult to hear the full range of discourses. Our sample broadly captured our interests, but we would have preferred more non-HM participants. Overall, 18 people participated in the online survey and were included in the analysis, thus achieving numbers robust for $\mathrm{Q}$ methodology (J. van Exel and G. de Graaf 2005, unpublished manuscript).

\section{Analysis}

Analysis of the Q sorts was performed using PQMethod (Schmolck 2017), a statistical program designed specifically for analysis of Q data. First, a correlation matrix of the Q sorts was developed, which was then subjected to principal components analysis (PCA). With Eigenvalues $>1$, the first three factors (Eigenvalues of 9.19, 1.62, and 1.42, respectively) were selected for varimax rotation, after which factors were flagged to associate participants with each factor. Participants were associated with a factor if they loaded high on that factor (at least 0.65) and not on other factors; participants that loaded high on multiple factors were excluded from the analysis. These "flaggings" were used to generate and interpret archetypal or idealized sorts for each factor, which we refer to as "viewpoints," based on the rank orderings of Z-scores for each factor. We also identified and interpreted "distinguishing statements," that is, the statements that were ranked significantly differently $(p<0.05)$ between the viewpoints.

Because participants interpret the statements within their own worldview, the traditional/systemic designation of the statement was only used as a starting point for our analysis. Our interpretation of the results considers the content of the statements themselves, as well as their designation as traditional or systemic.

\section{RESULTS}

Fifteen men and three women participated, ranging in age from 32-74 (Table 1). Although the average age was 52, that age is not in the sample, which had a gap between 45 and 62 (median $=45)$. Nine participants were farmers, one was an HM trainer, and the 
Table 1. Participant demographics, ordered by the factor on which they loaded. Note: HM = holistic management.

\begin{tabular}{|c|c|c|c|c|c|c|c|c|c|c|c|}
\hline$\#$ & Livelihood & $\begin{array}{c}\text { Years } \\
\text { farming }\end{array}$ & $\begin{array}{l}\text { Farming } \\
\text { HM? }\end{array}$ & Hectares & $\begin{array}{l}\text { Years HM } \\
\text { training }\end{array}$ & Age & Sex & Education & $\mathrm{F} 1$ & $\mathrm{~F} 2$ & F3 \\
\hline \multicolumn{12}{|c|}{ Factor 1} \\
\hline 05 & Farmer/ trainer & 42 & Yes & 130 & 15 & 65 & M & College & 0.74 & 0.40 & -0.01 \\
\hline 07 & Trainer & - & - & - & 32 & 62 & M & Master & 0.82 & -0.07 & 0.09 \\
\hline 08 & Farmer/ trainer & 21 & Yes & 1012 & 15 & 45 & M & College & 0.86 & 0.21 & 0.24 \\
\hline 11 & Farmer/ trainer & 45 & Yes & 1700 & 30 & 74 & M & Bachelor & 0.79 & 0.18 & 0.19 \\
\hline 13 & Farmer/ trainer & 16 & Yes & 890 & 25 & 72 & M & Bachelor & 0.75 & 0.35 & 0.12 \\
\hline 14 & Farmer/ trainer & 45 & Yes & 324 & 30 & 62 & M & Master & 0.78 & 0.16 & 0.33 \\
\hline 15 & Farmer/ trainer & 45 & Yes & 259 & 8 & 68 & M & College & 0.70 & 0.26 & 0.35 \\
\hline 16 & Farmer/ trainer & 40 & Yes & 550 & 9 & 62 & M & High school & 0.66 & 0.51 & 0.28 \\
\hline \multicolumn{12}{|c|}{ Factor 2} \\
\hline 09 & Farmer/ trainer & 8 & Yes & 17 & 14 & 43 & $\mathrm{~F}$ & Bachelor & 0.56 & 0.65 & 0.24 \\
\hline 12 & Farmer & 4 & Somewhat & 2428 & - & 30 & $\mathrm{~F}$ & College & -0.08 & 0.66 & 0.35 \\
\hline 18 & Farmer & 13 & Somewhat & 1012 & - & 32 & $\mathrm{~F}$ & Bachelor & 0.18 & 0.80 & -0.16 \\
\hline \multicolumn{12}{|c|}{ Factor 3} \\
\hline 06 & Farmer & 20 & Somewhat & 6070 & - & 45 & M & Bachelor & 0.39 & -0.21 & 0.71 \\
\hline 10 & Farmer & 3 & Yes & 134 & - & 35 & M & Bachelor & 0.26 & 0.23 & 0.80 \\
\hline 17 & Farmer & 35 & Somewhat & 2390 & - & 69 & M & $\mathrm{PhD}$ & 0.06 & 0.32 & 0.67 \\
\hline \multicolumn{12}{|c|}{ No factor } \\
\hline 01 & Farmer & 26 & No & 1214 & - & 41 & M & Bachelor & 0.49 & 0.51 & 0.29 \\
\hline 02 & Farmer & 18 & Yes & 20,234 & - & 39 & M & Master & 0.32 & 0.47 & 0.23 \\
\hline 03 & Farmer & 16 & Yes & 809 & - & 36 & $\mathrm{M}$ & High school & 0.51 & 0.59 & 0.20 \\
\hline 04 & Farmer & 20 & Yes & 1821 & - & 42 & M & Bachelor & 0.56 & 0.45 & 0.46 \\
\hline
\end{tabular}

remaining eight were both farmers and trainers. The trainer median age was 62 , and the nontrainer median was 39 . Their experience with farming and $\mathrm{HM}$ varied widely. Of the 17 farmers who participated, 12 identified as HM, 1 identified as non-HM, and 4 identified as somewhat HM. Education levels ranged from high school to $\mathrm{PhD}$.

From the 18 completed Q sorts, we used PCA to identify 3 viewpoints corresponding to factors 1,2 , and 3, which explain $34 \%, 19 \%$, and $15 \%$ of the variance, respectively. Eight sorts loaded on factor 1 , three sorts loaded on each of factors 2 and 3 , and four sorts loaded on multiple factors and were excluded from analysis (Table 1). These three viewpoints reflected differences both in level of systems thinking (some viewpoints agreed with more systems statements than others) and in type of systems thinking, in which viewpoints differed in their opinions on creativity, learning, and empowerment. We call the viewpoints the Fluent Systems Thinker, the Aspirational Systems Balancer, and the Independent Creative Farmer. The statistical strength suggests to us that these archetypal viewpoints do indeed exist, although it is likely that other viewpoints also exist. The average time to complete the survey was 26 minutes, ranging from 13-68 minutes. There was no relationship between time to complete and participant loading on any one factor.

There were some areas of consensus between all three viewpoints (Table 2). All felt that teamwork and collaboration were critical to a smooth-running operation (statement 27), and all disagreed that buying more insurance would be a useful way to deal with risk (statement 15). They were generally neutral about whether they break a problem down into smaller parts (statement 5) and about whether they find it difficult to be an expert on every aspect of the operation (statement 21). All agreed that having diversity is important for increasing resilience in an operation (statement 18). Each viewpoint is described below in more detail and the differences between them discussed. Each viewpoint subsection draws on a table of statistically distinguishing statements. Archetypal responses to other statements are included because of strength of feeling even if not statistically significantly different from other viewpoints; these can be referenced by statement number in Table 2.

\section{Viewpoint 1: Fluent Systems Thinker (34\% of variance explained)}

This viewpoint is defined by its strong adherence to core systems thinking (and HM) values: development and use of a farm goal (statement 4), identifying the root cause of a problem (statement 7), and mimicking nature (statement 30). These latter two sentiments distinguish it from viewpoints 2 and 3, who only slightly agreed or felt neutral about these issues (Table 3). This viewpoint tended to think of the farm as a self-sustaining unit that, when healthy, should need few inputs (statement 17) and felt that their management practices had important impacts on the local ecosystem and community (statement 25). They felt strongly that science and technology could not be counted on to solve every problem (statement 6).

The only systems' statements that this viewpoint slightly disagreed with were statements 2 and 8: "Some people put too much emphasis on the business end of farming; for me, it is also a lifestyle" and "Some problems seem too complex to have a perfect solution" (Table 2). They also slightly agreed with the traditional/ reductionist statement 10: "I've developed a pretty good routine on my operation, so year after year, things are pretty stable." These ratings speak to the experience and confidence of those in this viewpoint.

Unlike viewpoints 2 and 3, this group did not feel as strongly that learning new things was important to being a better farmer (statement 14). This may speak to the fact that these participants 
Table 2. List of statements in the Q set, the Z-score indicating the position of each statement relative to the others on each factor, and the rank of each statement on an archetypal sort of each factor $(\mathrm{T}=$ traditional/reductionist; $\mathrm{S}=$ systems thinking; $\uparrow=$ distinguishing statements).

\begin{tabular}{|c|c|c|c|c|c|c|c|}
\hline \multirow[b]{2}{*}{ \# } & \multirow[b]{2}{*}{ Statement } & \multicolumn{2}{|c|}{ Viewpoint 1} & \multicolumn{2}{|c|}{ Viewpoint 2} & \multicolumn{2}{|c|}{ Viewpoint 3} \\
\hline & & Z-score & Rank & Z-score & Rank & Z-score & Rank \\
\hline$\overline{1^{\mathrm{T}}}$ & $\begin{array}{l}\text { A successful farmer concentrates on production and is not sidetracked by } \\
\text { outside interests or activities }\end{array}$ & -1.08 & -2 & -0.85 & -1 & $-1.73 \dagger$ & $-3 \dagger$ \\
\hline $2^{\mathrm{S}}$ & $\begin{array}{l}\text { Some people put too much emphasis on the business end of farming; for me, it } \\
\text { is also a lifestyle }\end{array}$ & -0.62 & -1 & $1.53 \dagger$ & $2 \dagger$ & -0.39 & -1 \\
\hline $3^{\mathrm{T}}$ & $\begin{array}{l}\text { There are so many day-to-day problems that I often resort to band-aid } \\
\text { solutions, even if it isn't what I want in the long-term }\end{array}$ & -1.25 & -2 & $1.19 \dagger$ & $2 \dagger$ & -1.22 & -2 \\
\hline $4^{\mathrm{s}}$ & $\begin{array}{l}\text { I like to have a well-defined goal for my operation and make decisions that } \\
\text { bring me closer to it }\end{array}$ & 1.54 & 3 & 1.87 & 3 & $-0.34 \dagger$ & $0 \dagger$ \\
\hline $5^{\mathrm{T}}$ & $\begin{array}{l}\text { When I approach a problem, I break it down into smaller parts and deal with } \\
\text { each part separately }\end{array}$ & 0.11 & 0 & -0.16 & 0 & 0.34 & 1 \\
\hline $6^{\mathrm{T}}$ & $\begin{array}{l}\text { We may not be able to solve every problem yet, but science and technology will } \\
\text { eventually offer a solution for every problem }\end{array}$ & -1.63 & -3 & -1.53 & -3 & $-0.37 \dagger$ & $0 \dagger$ \\
\hline $7^{\mathrm{S}}$ & I like to identify the root cause of a problem before deciding what I will do & $1.53 \dagger$ & $3 \dagger$ & 0.67 & 1 & 0.51 & 1 \\
\hline $8^{\mathrm{S}}$ & Some problems seem too complex to have a perfect solution & -0.44 & -1 & 0.18 & 1 & 0.23 & 1 \\
\hline $9^{\mathrm{S}}$ & $\begin{array}{l}\text { Everything on my operation is connected, and even small decisions can have } \\
\text { cascading effects in unpredictable ways }\end{array}$ & 0.48 & 1 & 0.85 & 2 & $-0.46 \dagger$ & $-1 \dagger$ \\
\hline $10^{\mathrm{T}}$ & $\begin{array}{l}\text { I've developed a pretty good routine on my operation, so year after year, things } \\
\text { are pretty stable }\end{array}$ & $0.57 \dagger$ & $1 \dagger$ & -0.35 & 0 & -0.63 & -2 \\
\hline $11^{\mathrm{T}}$ & My operation is like a machine, with inputs and outputs that I control & -0.27 & 0 & -0.67 & -1 & -0.85 & -2 \\
\hline $12^{\mathrm{T}}$ & I enjoy the tradition of being a farmer & 0.10 & 0 & 0.17 & 0 & $1.85 \dagger$ & $3 \dagger$ \\
\hline $13^{\mathrm{S}}$ & Being creative and experimenting help me make better decisions & 0.97 & 1 & 0.34 & 1 & 1.53 & $3 \dagger$ \\
\hline $14^{\mathrm{S}}$ & I always like to learn new things to help me farm better & $0.83 \dagger$ & $1 \dagger$ & 1.70 & 3 & 1.73 & 3 \\
\hline $15^{\mathrm{T}}$ & In the face of more risk, I buy more insurance & -1.47 & -3 & -1.02 & -2 & -1.31 & -3 \\
\hline $16^{\mathrm{T}}$ & $\begin{array}{l}\text { I prefer to specialize in a few main crops or enterprises so that I don't spread } \\
\text { myself too thin }\end{array}$ & -0.39 & -1 & -0.85 & -2 & $0.85 \dagger$ & $2 \dagger$ \\
\hline $17^{\mathrm{S}}$ & A healthy farm is self-sustaining and needs few inputs to be profitable & $1.35 \dagger$ & $2 \dagger$ & -0.35 & -1 & -0.20 & 0 \\
\hline $18^{\mathrm{S}}$ & $\begin{array}{l}\text { Having diversity in an operation is important because it makes the farm more } \\
\text { resilient }\end{array}$ & 1.01 & 2 & 1.70 & 3 & 1.36 & 2 \\
\hline $19^{\mathrm{T}}$ & Anything worth knowing about my operation can be measured & -0.06 & 0 & $-1.36 \dagger$ & $-3 \dagger$ & -0.48 & -1 \\
\hline $20^{\mathrm{S}}$ & $\begin{array}{l}\text { Sometimes, you have to use your gut to make a decision; numbers are } \\
\text { important, but intuition is just as valuable }\end{array}$ & 0.03 & 0 & 0.17 & 0 & $1.08 \dagger$ & $2 \dagger$ \\
\hline $21^{\mathrm{T}}$ & $\begin{array}{l}\text { It is too difficult to be an expert on every aspect of my operation; I usually } \\
\text { prefer to follow the instructions of advisors }\end{array}$ & -0.37 & 0 & 0.00 & 0 & -0.54 & -1 \\
\hline $22^{\mathrm{T}}$ & $\begin{array}{l}\text { I'd like to try new things on my farm, but sometimes I feel restricted by other } \\
\text { people }\end{array}$ & -1.11 & -2 & -0.51 & -1 & 0.20 & 0 \\
\hline $23^{\mathrm{S}}$ & I see myself as the closest thing to an expert on my own operation & 0.55 & 1 & $-1.36 \dagger$ & $-3 \dagger$ & 0.74 & 1 \\
\hline $24^{\mathrm{T}}$ & $\begin{array}{l}\text { At a landscape level, decisions are made elsewhere, so my choices don't have a } \\
\text { huge effect }\end{array}$ & -1.81 & -3 & $-0.51 \dagger$ & $-1 \dagger$ & -1.87 & -3 \\
\hline $25^{\mathrm{S}}$ & $\begin{array}{l}\text { My management decisions have a big impact on the local ecosystem and } \\
\text { community }\end{array}$ & $0.99 \dagger$ & $2 \dagger$ & 0.18 & 1 & -0.51 & -1 \\
\hline $26^{\mathrm{T}}$ & $\begin{array}{l}\text { People in my operation have different goals or values, so we often end up } \\
\text { working in opposite directions }\end{array}$ & -1.09 & -2 & $-0.17 \dagger$ & $0 \dagger$ & -1.09 & -2 \\
\hline $27^{\mathrm{S}}$ & Teamwork and collaboration are key to a smooth-running operation & 1.14 & 2 & 1.03 & 2 & 1.28 & 2 \\
\hline $28^{\mathrm{T}}$ & Economic viability overrides all other farming considerations & -0.41 & -1 & $-1.35 \dagger$ & $-2 \dagger$ & -0.26 & 0 \\
\hline $29^{\mathrm{T}}$ & I only do conservation practices if they fit within my current management & -0.59 & -1 & -1.19 & -2 & $0.57 \dagger$ & $1 \dagger$ \\
\hline $30^{\mathrm{s}}$ & $\begin{array}{l}\text { I try to make management decisions so that my operation can mimic nature as } \\
\text { much as possible }\end{array}$ & $1.40 \dagger$ & $3 \dagger$ & 0.67 & 1 & -0.03 & 0 \\
\hline
\end{tabular}

were generally more experienced with farming and HM than the other groups (Table 1). Demographically, this viewpoint consisted of HM trainers: of the nine HM trainers included in the analysis, eight fell firmly into this group (the only female trainer loaded here but was stronger on viewpoint 2), seven of whom were also farmers. All were male, ages 45 to 72, with education ranging from high school to master's degrees. They had worked as HM trainers for 8-32 years, and those who farmed had done so for 16-45 years.

\section{Viewpoint 2: Aspirational Systems Balancer (19\% of variance explained)}

Like viewpoint 1 , this viewpoint felt strongly that science and technology will never be able to solve every problem (statement 6) and that it is important to have a farm goal (statement 4). However, they also felt that day-to-day issues often stopped them from moving toward their goals (statement 3; Table 4). They felt strongly that learning new things is important for farming better (statement 14). 
Table 3. Distinguishing statements for the Fluent Systems Thinker $(\mathrm{p}<0.5)$. Note: $\mathrm{T}=$ traditional/reductionist; $\mathrm{S}=$ systems thinking.

\begin{tabular}{|c|c|c|c|c|}
\hline & \multirow[b]{2}{*}{ Statement } & \multicolumn{3}{|c|}{ Rank } \\
\hline & & F1 & & F3 \\
\hline $7(\mathrm{~S})$ & $\begin{array}{l}\text { I like to identify the root cause of a problem before } \\
\text { deciding what I will do }\end{array}$ & 3 & 1 & 1 \\
\hline $30(\mathrm{~S})$ & $\begin{array}{l}\text { I try to make management decisions so that my } \\
\text { operation can mimic nature as much as possible }\end{array}$ & 3 & 1 & 0 \\
\hline $17(\mathrm{~S})$ & $\begin{array}{l}\text { A healthy farm is self-sustaining and needs few } \\
\text { inputs to be profitable }\end{array}$ & 2 & -1 & 0 \\
\hline $25(\mathrm{~S})$ & $\begin{array}{l}\text { My management decisions have a big impact on } \\
\text { the local ecosystem and community }\end{array}$ & 2 & 1 & -1 \\
\hline $14(\mathrm{~S})$ & $\begin{array}{l}\text { I always like to learn new things to help me farm } \\
\text { better }\end{array}$ & 1 & 3 & 3 \\
\hline $10(\mathrm{~T})$ & $\begin{array}{l}\text { I've developed a pretty good routine on my } \\
\text { operation, so year after year, things are pretty } \\
\text { stable }\end{array}$ & 1 & 0 & -2 \\
\hline
\end{tabular}

Table 4. Distinguishing statements for the Aspirational Systems Balancer $(\mathrm{p}<0.5)$. Note: $\mathrm{T}=$ traditional/reductionist; $\mathrm{S}=$ systems thinking.

\begin{tabular}{|c|c|c|c|c|}
\hline & \multirow[b]{2}{*}{ Statement } & \multicolumn{3}{|c|}{ Rank } \\
\hline & & F1 & $\mathrm{F} 2$ & F3 \\
\hline $2(\mathrm{~S})$ & $\begin{array}{l}\text { Some people put too much emphasis on the } \\
\text { business end of farming; for me, it is also a lifestyle }\end{array}$ & -1 & 2 & -1 \\
\hline $3(\mathrm{~T})$ & $\begin{array}{l}\text { There are so many day-to-day problems that I } \\
\text { often resort to band-aid solutions, even if it isn't } \\
\text { what I want in the long-term }\end{array}$ & -2 & 2 & -2 \\
\hline $26(\mathrm{~T})$ & $\begin{array}{l}\text { People in my operation have different goals or } \\
\text { values, so we often end up working in opposite } \\
\text { directions }\end{array}$ & -2 & 0 & -2 \\
\hline $24(\mathrm{~T})$ & $\begin{array}{l}\text { At a landscape level, decisions are made elsewhere, } \\
\text { so my choices don't have a huge effect }\end{array}$ & 3 & -1 & -3 \\
\hline $28(\mathrm{~T})$ & $\begin{array}{l}\text { Economic viability overrides all other farming } \\
\text { considerations }\end{array}$ & -1 & -2 & 0 \\
\hline $23(\mathrm{~S})$ & $\begin{array}{l}\text { I see myself as the closest thing to an expert on my } \\
\text { own operation }\end{array}$ & 1 & -3 & 1 \\
\hline $19(\mathrm{~T})$ & $\begin{array}{l}\text { Anything worth knowing about on my operation } \\
\text { can be measured }\end{array}$ & 0 & -3 & -1 \\
\hline
\end{tabular}

This viewpoint displayed lower levels of empowerment than the other groups; they strongly disagreed with statement 23: "I see myself as the closest thing to an expert on my own operation," with which viewpoints 1 and 3 slightly agreed. They only slightly disagreed that: "At a landscape level, decisions are made elsewhere, so my choices don't have a huge effect" (statement 24). They were also more concerned about quality of life; they enjoyed the lifestyle of farming more than the other groups (statement 2) and felt more strongly that economic viability should be balanced with other important considerations (statement 28). This viewpoint also felt more strongly than the others that some important things cannot be measured (statement 19).

This group largely adhered to systems thinking ideas, save a few key points: a lower level of empowerment (statement 23), a feeling that their goals were often undermined by day-to-day issues (statement 3), and also a slight disagreement with statement 17 , that "A healthy farm is self-sustaining and needs few inputs to be profitable." This group seems to appreciate the systems thinking paradigm, but struggle with applying the concepts in the day-today balance of their farming practice.

All three of the female participants in our study define this factor. These women were slightly younger than those in viewpoint 1 , ranging in age from 30-43, and had less experience with farming (8-13 years). Two considered themselves somewhat HM and practiced rotational grazing, although only one had recently taken grazing training, which was not HM. The third participant was a farmer as well as an HM trainer, with 14 years of training experience. Two had Bachelor's degrees, and one had attended college.

\section{Viewpoint 3: Independent Creative Farmer (15\% of variance explained)}

This viewpoint tended to embrace some of the more traditional elements of farming. It is distinguished by being the only viewpoint that enjoys the tradition of being a farmer (statement 12) and by preferring to specialize in a few main crops rather than diversifying their operation (statement 16; Table 5). This was also the only viewpoint to agree that conservation practices should only be undertaken if they fit within the current management (statement 29). Unlike viewpoints 1 and 2, who strongly supported goal setting and rejected the role of science and technology in farming, viewpoint 3 was neutral on these issues (statements 4 and 6, respectively). They also slightly disagreed with statement 9: "Everything on my operation is connected ...," with which factors 1 and 2 agreed.

Table 5. Distinguishing statements for the Independent Creative Farmer $(\mathrm{p}<0.5) . \mathrm{T}=$ traditional/reductionist; $\mathrm{S}=$ systems thinking.

\begin{tabular}{|c|c|c|c|c|}
\hline & \multirow[b]{2}{*}{ Statement } & \multicolumn{3}{|c|}{ Rank } \\
\hline & & $\mathrm{F} 1$ & $\mathrm{~F} 2$ & F3 \\
\hline $12(\mathrm{~T})$ & I enjoy the tradition of being a farmer & 0 & 0 & 3 \\
\hline $13(\mathrm{~S})$ & $\begin{array}{l}\text { Being creative and experimenting helps me make } \\
\text { better decisions }\end{array}$ & 1 & 1 & 3 \\
\hline $20(\mathrm{~S})$ & $\begin{array}{l}\text { Sometimes, you have to use your gut to make a } \\
\text { decision; numbers are important, but intuition is } \\
\text { just as valuable }\end{array}$ & 0 & 0 & 2 \\
\hline $16(\mathrm{~T})$ & $\begin{array}{l}\text { I prefer to specialize in a few main crops or } \\
\text { enterprises so that I don't spread myself too thin }\end{array}$ & -1 & -2 & 2 \\
\hline $29(\mathrm{~T})$ & $\begin{array}{l}\text { I only do conservation practices if they fit within } \\
\text { my current management }\end{array}$ & -1 & -2 & 1 \\
\hline $4(\mathrm{~S})$ & $\begin{array}{l}\text { I like to have a well-defined goal for my operation } \\
\text { and make decisions that bring me closer to it }\end{array}$ & 3 & 3 & 0 \\
\hline $6(T)$ & $\begin{array}{l}\text { We may not be able to solve every problem yet, } \\
\text { but science and technology will eventually offer a } \\
\text { solution for every problem }\end{array}$ & -3 & -3 & 0 \\
\hline $9(\mathrm{~S})$ & $\begin{array}{l}\text { Everything on my operation is connected, and } \\
\text { even small decisions can have cascading effects in } \\
\text { unpredictable ways }\end{array}$ & 1 & 2 & -1 \\
\hline $1(\mathrm{~T})$ & $\begin{array}{l}\text { A successful farmer concentrates on production } \\
\text { and is not sidetracked by outside interests or } \\
\text { activities }\end{array}$ & -2 & -1 & -3 \\
\hline
\end{tabular}

In contrast, however, this viewpoint also enjoys learning new things (statement 14) and being creative (statement 13). They felt strongly that farmers should lead well-balanced lives (statement 
1) and felt that their choices have an important impact on the landscape (statement 24). They felt that intuition can be very important for decision making, which factors 1 and 2 felt neutral about (statement 20).

This viewpoint disagreed slightly with three systems statements: "Some people put too much emphasis on the business end of farming; for me, it is also a lifestyle" (statement 2); "Everything on my operation is connected, and even small decisions can have cascading effects in unpredictable ways" (statement 9); and "My management decisions have a big impact on the local ecosystem and community" (statement 25). This factor also agreed with more traditional statements than factors 1 and 2 : in addition to statements 12,16 , and 29, this viewpoint also preferred to break a problem down into small parts (statement 5).

The viewpoint comprised 3 men, ranging in age from 35-69. All were farmers, and in general they had little experience with HM: one identified as an HM-practitioner but had only been farming for 3 years; the others had been farming for 20 and 35 years, and identified as somewhat HM. Two held bachelor's degrees, and one held a PhD.

\section{DISCUSSION}

We set out to explore levels and types of systems thinking among people who have engaged with HM to varying degrees, from wellestablished HM trainers to farmers who are just beginning to explore HM. Using Q methodology, we developed a concourse of 30 statements on topics representing a range from systems to traditional/reductionist thinking. Using the responses of 18 participants in Canada and the US, we identified 3 main viewpoints representing different types and levels of systems thinking: the Fluent Systems Thinker, with adherence to core systems ideas like tackling root causes and mimicking nature; the Aspirational Systems Balancer, who appreciates systems thinking ideas but struggles with application; and the Independent Creative Farmer, who adheres to more conventional farming traditions but values creativity and learning new things.

\section{Levels and types of systems thinking}

Are there different levels and types of systems thinking among people engaged in HM to varying degrees? Our results indicate that there is clearly a gradient of systems thinking among people engaging in HM. At one end is the Fluent Systems Thinker viewpoint, which consists of established HM trainers who adhere strongly to systems thinking ideas. This alignment confirms the link between HM and systems thinking that we, and others, have speculated about (Briske et al. 2011, 2014, Sherren et al. 2012, de Villiers et al. 2014, Nordborg and Röös 2016, Mann and Sherren 2018). The statements used for sorting do not specify any particular agricultural commodity, so it may be useful for assessing systems thinking in a range of agricultural contexts. On the other end of the gradient, the Independent Creative Farmer (with less experience in HM) had a lower adherence to systems thinking ideas: they disagreed with more systems statements and agreed with more traditional/reductionist statements. Higher adherence to HM seems to be linked to systems thinking perspectives, although the direction of causation remains unclear.

However, the story is more complex than a simple gradient of systems thinking levels: we also see different types of systems thinking dominating in different groups. The Fluent Systems Thinkers scored high on many systems thinking statements but did not especially value creativity or learning new things. This viewpoint seems to have fully internalized the HM paradigm, perhaps to such a point that they feel there is little left to learn. In contrast, the Independent Creative Farmer held some traditional, reductionist ideas but also displayed high levels of creativity and empowerment. They appear to be open to new farming methods but independent of HM orthodoxies (Chiaviello 2000). The Aspirational Systems Balancer falls in the middle: this viewpoint adhered strongly to many systems thinking ideas but struggled with applying, and feeling empowered to apply, those ideas in practice. Lack of empowerment has been linked to systems thinking capacity (Ackerman et al. 1995).

\section{Empowerment, gender, and systems thinking}

The Aspirational Systems Balancers did not see themselves as experts on their own farm, struggled with day-to-day issues that stop them from achieving their goals, and did not feel strongly that their decisions could have a major effect on the landscape. These issues, i.e., motivation and self-rating of ability, are important factors that affect individuals' capacities to deal with complex systems in simulation studies (Ackerman et al. 1995). Empowerment is important for effectively using systems thinking in practice, a factor that has also been identified by HM trainers as critically important for HM practitioners' success (Mann and Sherren 2018). Our data do not allow us to speculate about onfarm outcomes of different levels or types of systems thinking, although this would be valuable future research.

The participants that defined this viewpoint were, perhaps coincidentally, all women. Other systems literature has also identified women as typically having lower perceptions of selfefficacy, which influences goal setting, analytical thinking, and outcomes in complex decision making (Bandura and Wood 1989, Ackerman et al. 1995). Perceived self-efficacy likely has an intermediary effect on systems thinking capacity, because women typically perform worse than men in complex systems simulations (Bandura and Wood 1989, Ackerman et al. 1995, Wittmann and Hattrup 2004). Others have hypothesized that the higher risk tolerance of men inspires more dramatic responses in a simulation game, allowing them to see the system structure more clearly (Wittmann and Hattrup 2004). Our data hint at this link between gender and empowerment in complex systems thinking but do not support any assessment of the effects of gender on actual ability or systems outcomes. Future work in HM should explore this link and the associated outcomes on farm systems performance, perhaps using endogenous goals to evaluate success (i.e., the goals set by farmers during the HM planning process) rather than exogenous assumptions of economic rationality.

A further difference between the Aspirational Systems Balancer and the other viewpoints was a greater concern for quality of life: enjoying the lifestyle of farming and balancing economic considerations with other values. This, too, has been noted by HM trainers, who perceived that women are drawn to HM for quality of life or health reasons, whereas men focus on productivity (Mann and Sherren 2018). Holistic management farms in Australia more often seem to be collaborations between life partners than run by sole operators, leading to more family time despite increased labor (Sherren et al. 2012) and potential 
benefits for well-being. With only three women participating in our study, the gender factor here is tenuous. There are other differences between the participants that define each viewpoint, such as age, experience with farming, and experience with HM. However, further research is warranted to test the extent to which gender holds as a factor in explaining differences between these discourses.

Creativity, learning, and goal setting in complex decision making The Independent Creative Farmer is distinguished by being the only viewpoint to highly value creativity; along with the Aspirational Systems Balancer, they also highly value learning new things. The Fluent Systems Thinker was ambivalent on both. In systems research, however, the role of creativity and learning in systems thinking is complex. Systems researchers advocate for breaking paradigms, crossing boundaries, and thinking outside the box (Meadows 2008). Research shows that being highly familiar with a situation makes for poorer learning outcomes and more difficulty applying new skills (Bakken 1993), indicating the importance of being open to new ways of thinking and doing. This poses a challenge for farmers who are entrenched in their own farm and own paradigm, which likely reduces their ability to learn. On the other hand, creativity, along with mental speed, verbal processing speed, short-term memory, can also have negative impacts on performance in complex system simulations, leading to the hypothesis that reasoning and deep thinking are more important than fast thinking (Wittmann and Hattrup, 2004). The willingness of the Independent Creative Farmer to learn new things may be what attracted them to HM, whereas their autonomy might keep them from fully aligning. Creativity may also bode well for their ability to learn systems thinking ideas, but its effect on systems outcomes remains unclear.

The Independent Creative Farmer is also the only viewpoint to highly value experimentation. Systematic thinking and continuous experimentation are both important for developing mental models and learning system processes (Sterman 1994, Vollmeyer et al. 1996). Closed-loop thinking is particularly effective in complex task simulations, in which an individual first conceives of the problem, makes a plan, takes action, and then returns to the conception stage to analyze the effects of their action and develop a new plan (Maani and Maharaj 2004, Bußwolder 2015). This is effective because complex systems can only be understood incrementally (Maani and Maharaj 2004). Savory advocates for a similar type of closed-loop thinking with his plan-monitor-control-replan model (Savory 2016). Using this effectively in real life, however, i.e., learning about and affecting change in the system that one inhabits, is extremely difficult (Sterman 1994). Many farmers prefer to avoid uncertainty and simplify decision making (Villamor and Badmos 2016), but the creativity, experimentation, and willingness to learn exhibited by the Independent Creative Farmer indicates a greater acceptance for uncertainty, which is a key trait of systems thinkers (Meadows 2008).

Both the Fluent Systems Thinker and the Aspirational Systems Balancer felt strongly that goal setting was important for their farm. The Independent Creative Farmer, however, felt neutral about goal setting. Holistic management asks farmers to create a holistic context or farm goal: the purpose of the whole under management, the desired quality of life, and the resource base that must be in place (Savory 2016). Goal setting improves outcomes in complex systems simulations, although a goal that is highly specific limits understanding of the system structure and therefore reduces knowledge transferability (Vollmeyer et al. 1996). Developing a more holistic goal, such as in HM, may be better.

\section{CONCLUSION}

Farmers face complex management decisions every day and must consider a multitude of economic, social, and environmental factors when choosing the best course of action. Systems thinking can help farmers cope with complexity and improve their decision making, and HM is one concrete application of systems thinking in agriculture. We identified three viewpoints on systems thinking ideas among farmers and HM trainers who are engaged in HM to varying degrees. The dominant group, made up of long-time HM trainers, were Fluent Systems Thinkers who adhered to most systems thinking ideas but had low value for further creativity and learning in their own operations. The Aspirational Systems Balancer agreed with many systems ideas but struggled with empowerment and application of those ideas in practice. The Independent Creative Farmer, with less farming or HM experience, had lower engagement with systems ideas, but valued creativity and learning new things. These groups differed in their levels of empowerment, creativity, goal-setting, and willingness to learn, all of which can affect capacity to manage complex decisions. Gender also seems to play a role, as women in the sample displayed lower levels of empowerment, although more research is needed. Stronger engagement with HM seems to correlate with stronger adherence to systems thinking ideas, although the direction of causation remains elusive. Our research indicates that farmers who engage in HM to varying degrees approach decision making very differently, and future research should explore whether these differences result in changes to on-farm practices or outcomes.

\section{Responses to this article can be read online at: http://www.ecologyandsociety.org/issues/responses. php/11092}

\section{Acknowledgments:}

This work was funded by the Social Sciences and Humanities Research Council of Canada via an Insight Grant (\#435-2015-0702,2015-2019) to Dr Kate Sherren (PI). The study methods were reviewed and approved by the Social Sciences \& Humanities Research Ethics Board at Dalhousie University (REB \# 2018-4403). The authors acknowledge Kristine Dahl for her feedback on the statement concourse and assistance recruiting ranchers. Finally, we are grateful to the 18 practitioners who participated in this research, and the 2 anonymous reviewers for helpful feedback.

\section{LITERATURE CITED}

Abaidoo, S., and H. Dickinson. 2002. Alternative and conventional agricultural paradigms: evidence from farming in southwest Saskatchewan. Rural Sociology 67(1):114-131. https:// doi.org/10.1111/j.1549-0831.2002.tb00096.x 
Ackerman, P. L., R. Kanfer, and M. Goff. 1995. Cognitive and noncognitive determinants and consequences of complex skill acquisition. Journal of Experimental Psychology: Applied 1 (4):270-304. https://doi.org/10.1037/1076-898X.1.4.270

Alfaro-Arguello, R., S. A. W. Diemont, B. G. Ferguson, J. F. Martin, J. Nahed-Toral, J. D. Álvarez-Solís, and R. Pinto Ruíz. 2010. Steps toward sustainable ranching: an emergy evaluation of conventional and holistic management in Chiapas, Mexico. Agricultural Systems 103(9):639-646. https://doi.org/10.1016/j. agsy.2010.08.002

Allsopp, N. 2013. Adaptive management for complex communal rangelands in South Africa. African Journal of Range and Forage Science 30(1-2):65-69. https://doi.org/10.2989/10220119.2013.781062

Bakken, B. E. 1993. Learning and transfer of understanding in dynamic decision environments. Dissertation, Massachusetts Institute of Technology, Cambridge, Massachusetts, USA. [online] URL: https://dspace.mit.edu/bitstream/handle/1721.1/12255/30757735-MIT.pdf?sequence $=2$

Bandura, A., and R. Wood. 1989. Effect of perceived controllability and performance standards on self-regulation of complex decision making. Journal of Personality and Social Psychology 56(5):805-814. https://doi.org/10.1037/0022-3514.56.5.805

Baur, I., K. Liechti, and C. R. Binder. 2014. Why do individuals behave differently in commons dilemmas? The case of alpine farmers using common property pastures in Grindelwald, Switzerland. International Journal of the Commons 8(2):657-685. https://doi.org/10.18352/ijc.469

Bawden, R. J. 1991. Systems thinking and practice in agriculture. Journal of Dairy Science 74(7):2362-2373. https://doi. org/10.3168/jds.S0022-0302(91)78410-5

Bennet, A., and D. Bennet. 2008. The decision-making process in a complex situation. Pages 3-20 in F. Burstein, and C. W. Holsapple, editors. Handbook on decision support systems 1 Springer-Verlag, Berlin, Heidelberg. https://doi.org/10.1007/978-3-540-48713-5 1

Berkes, F. 2003. Alternatives to conventional management: lessons from small-scale fisheries. Environments 31(1):5-21.

Bestelmeyer, B. T., A. Ash, J. R. Brown, B. Densambuu, M. Fernández-Giménez, J. Johanson, M. Levi, D. Lopez, R. Peinetti, L. Rumpff, and P. Shaver. 2017. State and transition models: theory, applications, and challenges. Pages 303-345 in D. D. Briske, editor. Rangeland systems: processes, management and challenges. Springer, New York, New York, USA. https://doi. org/10.1007/978-3-319-46709-2 9

Bosch, O. J. H., C. A. King, J. L. Herbohn, I. W. Russell, and C. S. Smith. 2007. Getting the big picture in natural resource management - systems thinking as 'method' for scientists, policy makers and other stakeholders. Systems Research and Behavioral Science 24(2):217-232. https://doi.org/10.1002/sres.818

Briske, D. D., A. J. Ash, J. D. Derner, and L. Huntsinger. 2014. Commentary: a critical assessment of the policy endorsement for holistic management. Agricultural Systems 125:50-53. https://doi. org/10.1016/j.agsy.2013.12.001

Briske, D. D., J. D. Derner, J. R. Brown, S. D. Fuhlendorf, W. R. Teague, K. M. Havstad, R. L. Gillen, A. J. Ash, and W. D. Willms.
2008. Rotational grazing on rangelands: reconciliation of perception and experimental evidence. Rangeland Ecology and Management 61(1):3-17. https://doi.org/10.2111/06-159R.1

Briske, D. D., N. F. Sayre, L. Huntsinger, M. Fernandez-Gimenez, B. Budd, and J. D. Derner. 2011. Origin, persistence, and resolution of the rotational grazing debate: integrating human dimensions into rangeland research. Rangeland Ecology and Management 64(4):325-334. https://doi.org/10.2111/REM-D-10-00084.1

Brodt, S., K. Klonsky, and L. Tourte. 2006. Farmer goals and management styles: implications for advancing biologically based agriculture. Agricultural Systems 89(1):90-105. https://doi. org/10.1016/j.agsy.2005.08.005

Brown, S. R. 1980. Political subjectivity: applications of $Q$ methodology in political science. Yale University Press, New Haven, Connecticut, USA.

Brown, S. R. 1993. A primer on Q methodology. Operant Subjectivity 16(3/4):91-138. http://dx.doi.org/10.15133/j.os.1993.002

Brunson, M. W. 2012. The elusive promise of social-ecological approaches to rangeland management. Rangeland Ecology and Management 65(6):632-637. https://doi.org/10.2111/REM-D-11-00117.1

Bußwolder, P. 2015. The effect of a structured method on mental model accuracy and performance in a complex task. Systems 3 (4):264-286. https://doi.org/10.3390/systems3040264

Carter, J., A. Jones, M. O'Brien, J. Ratner, and G. Wuerthner. 2014. Holistic management: misinformation on the science of grazed ecosystems. International Journal of Biodiversity 2014:163431. https://doi.org/10.1155/2014/163431

Chiaviello, A. 2000. Anarchy in range science: Allan Savory and the rhetoric of holistic resource management. Pages 301-320 in N. W. Coppola and B. Karis, editors. Technical communication, deliberative rhetoric, and environmental discourse: connections and directions. Ablex Publishing, Stamford, Connecticut, USA.

Cruz, M., R. Quiroz, and M. Herrero. 2007. Use of visual material for eliciting shepherds' perceptions of grassland in highland Peru. Mountain Research and Development 27(2):146-152. https://doi. org/10.1659/mrd.0793

Dalgaard, T., N. J. Hutchings, and J. R. Porter. 2003. Agroecology, scaling and interdisciplinarity. Agriculture, Ecosystems and Environment 100(1):39-51. https://doi.org/10.1016/S0167-8809 (03)00152-X

Davies, B. B., and I.D. Hodge. 2007. Exploring environmental perspectives in lowland agriculture: a $\mathrm{Q}$ methodology study in East Anglia, UK. Ecological Economics 61(2-3):323-333. https:// doi.org/10.1016/j.ecolecon.2006.03.002

de Villiers, A. C., K. J. Esler, and A. T. Knight. 2014. Social processes promoting the adaptive capacity of rangeland managers to achieve resilience in the Karoo, South Africa. Journal of Environmental Management 146:276-283. https://doi.org/10.1016/ j.jenvman.2014.08.005

Hahn, T., and B. Nykvist. 2017. Are adaptations self-organized, autonomous, and harmonious? Assessing the social-ecological resilience literature. Ecology and Society 22(1):12. https://doi. org/10.5751/es-09026-220112 
Hall, C., and A. Wreford. 2012. Adaptation to climate change: the attitudes of stakeholders in the livestock industry. Mitigation and Adaptation Strategies for Global Change 17(2):207-222. https://doi.org/10.1007/s11027-011-9321-y

Hamadou, I., N. Moula, S. Siddo, M. Issa, H. Marichatou, P. Leroy, and N. Antoine-Moussiaux. 2016. Mapping stakeholder viewpoints in biodiversity management: an application in niger using Q methodology. Biodiversity and Conservation 25 (10):1973-1986. https://doi.org/10.1007/s10531-016-1175-X

Hawkins, H.-J. 2017. A global assessment of holistic planned grazing ${ }^{\mathrm{TM}}$ compared with season-long, continuous grazing: metaanalysis findings. African Journal of Range and Forage Science 34 (2):65-75. https://doi.org/10.2989/10220119.2017.1358213

Holechek, J. L., H. Gomes, F. Molinar, D. Galt, and R. Valdez. 2000. Short-duration grazing: the facts in 1999. Rangelands 22 (1):18-22. https://doi.org/10.2458/azu_rangelands_v22i1_holechek

Holling, C. S., and G. K. Meffe. 1996. Command and control and the pathology of natural resource management. Conservation Biology 10(2):328-337. https://doi.org/10.1046/j.1523-1739.1996.10020328. $\underline{\mathrm{x}}$

Hruska, T., L. Huntsinger, M. Brunson, W. Li, N. Marshall, J. L. Oviedo, and H. Whitcomb. 2017. Rangelands as social-ecological systems. Pages 263-302 in D. Briske, editor. Rangeland systems. Springer, Berlin, Germany. https://doi.org/10.1007/978-3-319-46709-2 8

Jacobo, E. J., A. M. Rodríguez, N. Bartoloni, and V. A. Deregibus. 2006. Rotational grazing effects on rangeland vegetation at a farm scale. Rangeland Ecology and Management 59(3):249-257. https:// doi.org/10.2111/05-129r1.1

King, C. A. 2008. Community resilience and contemporary agriecological systems: reconnecting people and food, and people with people. Systems Research and Behavioral Science 25 (1):111-124. https://doi.org/10.1002/sres.854

Klerkx, L., N. Aarts, and C. Leeuwis. 2010. Adaptive management in agricultural innovation systems: the interactions between innovation networks and their environment. Agricultural Systems 103(6):390-400. https://doi.org/10.1016/j.agsy.2010.03.012

Li, W., and Y. Li. 2012. Managing rangeland as a complex system: how government interventions decouple social systems from ecological systems. Ecology and Society 17(1):9. https://doi. org/10.5751/ES-04531-170109

Lien, A. M., C. Svancara, W. Vanasco, G. B. Ruyle, and L. LópezHoffman. 2017. The land ethic of ranchers: a core value despite divergent views of government. Rangeland Ecology and Management 70(6):787-793. https://doi.org/10.1016/j.rama.2017.06.004

Linstaedter, A., A. Kuhn, C. Naumann, S. Rasch, A. SandhageHofmann, W. Amelung, J. Jordaan, C. C. Du Preez, and M. Bollig. 2016. Assessing the resilience of a real-world social-ecological system: lessons from a multidisciplinary evaluation of a South African pastoral system. Ecology and Society 21(3):35. https:// doi.org/10.5751/ES-08737-210335

Louah, L., M. Visser, A. Blaimont, and C. De Cannière. 2017. Barriers to the development of temperate agroforestry as an example of agroecological innovation: mainly a matter of cognitive lock-in? Land Use Policy 67:86-97. https://doi. org/10.1016/j.landusepol.2017.05.001
Maani, K. E., and V. Maharaj. 2004. Links between systems thinking and complex decision making. System Dynamics Review 20(1):21-48. https://doi.org/10.1002/sdr.281

Mann, C., and K. Sherren. 2018. Holistic management and adaptive grazing: a trainers' view. Sustainability 10:1848. https:// doi.org/10.3390/su10061848

Mannen, D., H. Scott, T. Kuijper, and T. Porter. 2012. Sustainable organizing: a multiparadigm perspective of organizational development and permaculture gardening. Journal of Leadership and Organizational Studies 19(3):355-368. https://doi. org/10.1177/1548051812442967

Meadows, D. H. 2008. Thinking in systems: a primer. Chelsea Green, Sterling, Virginia.

Mitchell, J., R. Harben, G. Sposito, A. Shrestha, D. Munk, G. Miyao, R. Southard, H. Ferris, W. R. Horwath, E. Kueneman, J. Fisher, M. Bottens, P. Hogan, R. Roy, J. Komar, D. Beck, D. Reicosky, M. Leinfelder-Miles, B. Aegerter, J. Six, T. Barcellos, D. Giacomazzi, A. Sano, J. Sanchez, M. Crowell, J. Diener, D. Cordova, T. Cordova, and J. Rossiter. 2016. Conservation agriculture: systems thinking for sustainable farming. California Agriculture 70(2):53-56. https://doi.org/10.3733/ca.v070n02p53

Nordhagen, S., U. Pascual, and A. G. Drucker. 2017. Feeding the household, growing the business, or just showing off? Farmers' motivations for crop diversity choices in Papua New Guinea. Ecological Economics 137:99-109. https://doi.org/10.1016/j. ecolecon.2017.02.025

Nordborg, M., and E. Röös. 2016. Holistic management: a critical review of Allan Savory's grazing method. SLU/EPOK - Centre for Organic Food \& Farming, and Chalmers, Uppsala, Sweden. http://publications.lib.chalmers.se/records/fulltext/244566/local_244566. pdf

Parkins, J. R., and K. Sherren. In press. Identifying energy discourses across scales in Canada with $Q$ methodology and survey research. Pages in J. Jacquet, J. Haggerty, and G. Theodori, editors. Coordinating research on the social impacts of energy development: synthesis across the social sciences. Social Ecology Press and the International Association for Society and Natural Resources, Logan, Utah, USA.

Pereira, M. A., J. R. Fairweather, K. B. Woodford, and P. L. Nuthall. 2016. Assessing the diversity of values and goals amongst Brazilian commercial-scale progressive beef farmers using Q-methodology. Agricultural Systems 144:1-8. https://doi. org/10.1016/j.agsy.2016.01.004

Potschin, M., and R. Haines-Young. 2013. Landscapes, sustainability and place-based analysis of ecosystem services. Landscape Ecology 28(6):1053-1065. https://doi.org/10.1007/ s10980-012-9756-X

Pruneddu, A. 2016. Q-sorTouch. Q-sorTouch, Manchester, UK. https://qsortouch.com/\#/

Robinson, L. W. 2009. A complex-systems approach to pastoral commons. Human Ecology 37(4):441-451. https://doi.org/10.1007/ s10745-009-9253-2

Savory, A. 2016. Holistic management: a commonsense revolution to restore our environment. Island, Washington, D.C., USA. Island. 
Sayre, N. F. 2017. The politics of scale: a history of rangeland science. University of Chicago Press, Chicago, Illinois, USA. https://doi.org/10.7208/chicago/9780226083391.001.0001

Schiere, J. B., R. Groenland, A. Vlug, and H. Van Keulen. 2004. System thinking in agriculture: an overview. Pages 1-27 in K. G. Rickert, editor. Emerging challenges for farming systems - lessons from Australian and Dutch agriculture. Rural Industries Research and Development Corporation, Canberra, Australia.

Schmolck, P. 2017. PQMethod. PQMethod, Gilching, Germany. http://schmolck.userweb.mwn.de/qmethod/

Sherren, K., J. Fischer, and I. Fazey. 2012. Managing the grazing landscape: insights for agricultural adaptation from a middrought photo- elicitation study in the Australian sheep-wheat belt. Agricultural Systems 106(1):72-83. https://doi.org/10.1016/ j.agsy.2011.11.001

Sherren, K., and C. Kent. 2019. Who's afraid of Allan Savory? Scientometric polarization on holistic management as competing understandings. Renewable Agriculture and Food Systems 34:77-92. https://doi.org/10.1017/S1742170517000308

Spielman, D. J. 2005. Innovation systems perspectives on developing-country agriculture: a critical review. International Food Policy Research Institute, Washington, D.C., USA. https:// ageconsearch.umn.edu/bitstream/59692/2/isnardp02.pdf

Sterman, J. D. 1994. Learning in and about complex systems. System Dynamics Review 10(2):291-330. https://doi.org/10.1002/ $\underline{\text { sdr.4260100214 }}$

Stinner, D. H., B. R. Stinner, and E. Martsolf. 1997. Biodiversity as an organizing principle in agroecosystem management: case studies of holistic resource management practitioners in the USA. Agriculture, Ecosystems and Environment 62(2):199-213. https:// doi.org/10.1016/S0167-8809(96)01135-8

Sweeney, L. B., and J. D. Sterman. 2000. Bathtub dynamics: initial results of a systems thinking inventory. System Dynamics Review 16(4):249-286. https://doi.org/10.1002/sdr.198

Thompson, A. W., S. Dumyahn, L. S. Prokopy, S. Amberg, A. Baumgart-Getz, J. Jackson-Tyree, R. Perry-Hill, A. Reimer, K. Robinson, and A. Saylor Mase. 2013. Comparing random sample $\mathrm{Q}$ and $\mathrm{R}$ methods for understanding natural resource attitudes. Field Methods 25(1):25-46. https://doi.org/10.1177/1525822X12453516

Villamor, G. B., and B. K. Badmos. 2016. Grazing game: a learning tool for adaptive management in response to climate variability in semiarid areas of Ghana. Ecology and Society 21 (1):39. https://doi.org/10.5751/ES-08139-210139

Vollmeyer, R., B. D. Burns, and K. J. Holyoak. 1996. The impact of goal specificity on strategy use and the acquisition of problem structure. Cognitive Science 20(1):75-100. https://doi.org/10.1207/ $\underline{\mathrm{s} 15516709 \operatorname{cog} 2001 \quad 3}$

Wittmann, W. W., and K. Hattrup. 2004. The relationship between performance in dynamic systems and intelligence. Systems Research and Behavioral Science 21(4):393-409. https://doi. org/10.1002/sres. 653
Yirdaw, E., M. Tigabu, and A. Monge. 2017. Rehabilitation of degraded dryland ecosystems - review. Silva Fennica 51(1B):1673. https://doi.org/10.14214/sf.1673 